\title{
Risk Factors Associated with MDR-TB among Tuberculosis Patients in Ibadan, Oyo state, Nigeria
}

\author{
Akinleye C.A ${ }^{1^{*}}$, Onabule $\mathrm{A}^{2}$, Oyekale A .O ${ }^{3}$, Akindele M.O², Babalola O.J ${ }^{4}$, Olarewaju S.O
}

\begin{abstract}
Introduction: In Nigeria, patients accessing Directory Observed Therapy (DOTS) treatment are exposed to resistance to anti-TB drugs, hence is considered a priority, only few studies have focused on the relevant risk factors, Factors leading to development of drug resistance need to be understood to develop appropriate control strategies for national programs
\end{abstract}

Method: The study was a cross sectional study design. Multistage sampling technique was employed in the selection of403 tuberculosis patients in Ibadan North Local Government Area of Oyo State. Data were collected using self-administered structured questionnaire, and analyzed using SPSS version 25. Level of significance was set at $\mathrm{P}<0.05$.

Results: Fifty three (13.2\%) of the total respondent had Multidrug Resistant TB (MDR-TB) which is more among the males 36(67.9\%) ( $\mathrm{p}>0.05)$. Education and Occupation shows a significant association with MDR-TB, $\left(\chi^{2}=24.640, p=\right.$ $0.007)$ and $\left(\chi^{2}=14.416, p=0.006\right)$ respectively,risk factors such asprevious TB treatment and Adherence with treatment regimen $(\mathrm{r}=0.270, p<0.05)$, HIV $(\mathrm{r}=0.168, p<0.05)$ and smoking $(\beta=0.107, \mathrm{t}=2.144, p<0.05)$ were statistically associated with development of acquired MDR-TB.

Conclusion: This finding revealed that Previous TB treatment andAdherence with treatment regimen were found to be the major risk factor for MDR-TB. Targeted educational intervention for patients and their contacts may minimize the nonadherence with prescribed TB treatment and lessen MDR-TB magnitude. High quality directly observed treatment should be strengthened to ensure that the previously treated patients can receive standard and regular regimens.

Keywords: TB Patients, MDR-TB, tuberculosis, Risk factors.

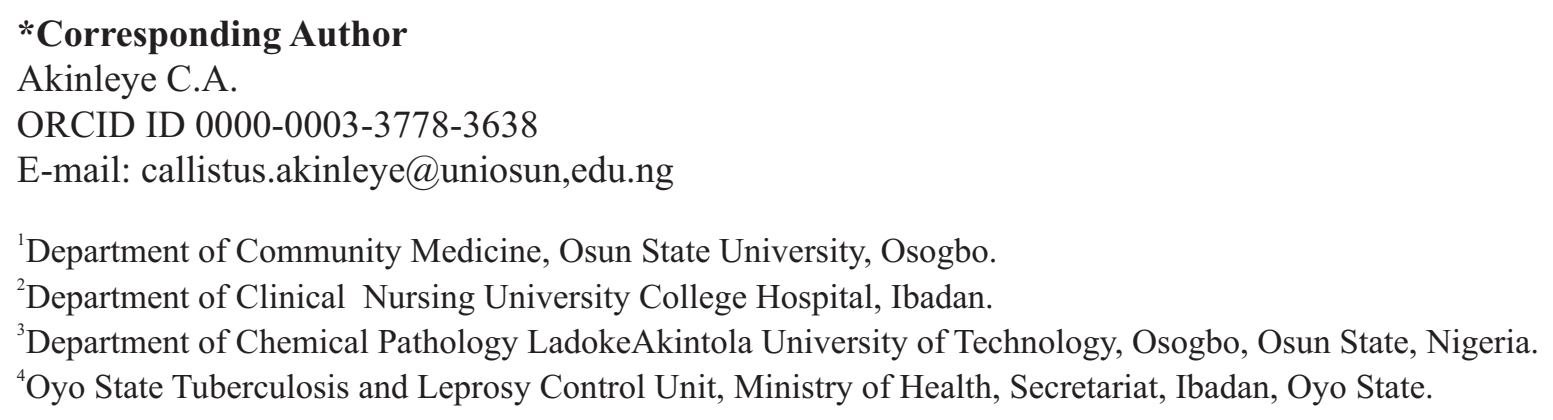




\title{
Facteurs de risque associés à la MDR-TB parmi les patients tuberculeux à Ibadan, état d'Oyo, Nigéria
}

\author{
Akinleye C.A ${ }^{1^{*}}$, Onabule $\mathrm{A}^{2}$, Oyekale A. $\mathrm{O}^{3}$, Akindele M.O ${ }^{2}$, Babalola O.J ${ }^{4}$, Olarewaju S.O
}

\section{Résumé}

Introduction: Au Nigéria, les patients accédant au traitement DOTS (Directory Observed Therapy) sont exposés à une résistance aux médicaments antituberculeux, ce qui est considéré comme une priorité, seules quelques études se sont concentrées sur les facteurs de risque pertinents. Les facteurs menant au développement d'être compris pour développer des stratégies de contrôle appropriées pour les programmes nationaux.

Méthode de l'étude: L'étude était un plan d'étude transversale. Une technique d'échantillonnage à plusieurs degrés a été utilisée pour sélectionner 403 patients tuberculeux dans la région du gouvernement local d'Ibadan Nord de l'état d'Oyo. Les données ont été collectées à l'aide d'un questionnaire structuré auto-administré et analysées à l'aide de la version $25 \mathrm{du}$ SPSS. Le niveau de signification a été fixé à $\mathrm{P}<0,05$.

Résultats de l'étude: Cinquante-trois $(13,2 \%)$ des répondants totaux avaient une tuberculose multi résistante (MDR-TB), ce qui est plus parmi les hommes $36(67,9 \%)(\mathrm{p}>0,05)$. L'éducation et la profession montrent une association significative avec la TB-MR, $(\chi 2=24,640, p=0,007)$ et $(\chi 2=14,416, p=0,006)$ respectivement, des facteurs de risque tels que le traitement antituberculeux antérieur et l'observance du schéma thérapeutique $(\mathrm{r}=$ $0,270, p<0,05)$, le VIH $(r=0,168, p<0,05)$ et le tabagisme $(\beta=0,107, t=2,144, p<0,05)$ étaient statistiquement associés au développement de la TB-MR acquise.

Conclusion: Ce résultat a révélé que le traitement antituberculeux antérieur et l'observance du schéma thérapeutique étaient les principaux facteurs de risque de TB-MR. Une intervention éducative ciblée pour les patients et leurs contacts peut minimiser la non-observance du traitement antituberculeux prescrit et réduire l'ampleur de la TB-MR. Un traitement de haute qualité directement observé doit être renforcé pour garantir que les patients précédemment traités puissent recevoir des schémas standards et réguliers.

Mots-clés: Patients TB, MDR-TB, tuberculose, facteurs de risque

\footnotetext{
*Corresponding Author

Akinleye C.A.

ORCID ID 0000-0003-3778-3638

E-mail: callistus.akinleye@uniosun,edu.ng

${ }^{1}$ Department of Community Medicine, Osun State University, Osogbo.

${ }^{2}$ Department of Clinical Nursing University College Hospital, Ibadan.

${ }^{3}$ Department of Chemical Pathology LadokeAkintola University of Technology, Osogbo, Osun State, Nigeria.

${ }^{4}$ Oyo State Tuberculosis and Leprosy Control Unit, Ministry of Health, Secretariat, Ibadan, Oyo State.
} 


\section{INTRODUCTION}

Tuberculosis (TB) still remains a major public health issue across the world. According to the World Health Organisation (WHO) global report 2016, among 10.4 million incident TB cases worldwide, $3.9 \%$ are estimated to have had rifampicin- or multidrugresistant tuberculosis (MDR/RR-TB) in 2015 (1). In addition, $21 \%$ of previously treated TB cases were estimated to have had MDR/RR-TB in the same year (1). MDR-TB is caused by strains of $M$. tuberculosis that is resistant to both isoniazid and rifampicin. Drug-resistant TB (DR-TB) patients require prolonged and expensive treatment using second-line medications that are less effective and more toxic (1).

Workicho et.al. (2) reported that, tuberculosis is one of the major public health problems that is most frequently, the cause of death among adults despite being nearly $100 \%$ curable. It has also affected almost one-third of the world's population. Currently the global strategy to control TB is through preventing infection by efficient case finding and treatment which helps to stop the infection from progressing to an active disease. One of the challenges in controlling $\mathrm{TB}$ is the presence of resistance (2).

Although many efforts have been made over the past 20 years to control TB, the World Health Organization (WHO), estimated that in 2014, there were 4.8 million new cases of MDR-TB globally and approximately 1.9 million associated deaths. Moreover, compared with the drug sensitive TB, treatment for multidrug-resistant (MDR-TB) and extensively drug-resistant tuberculosis (XDR-TB) can cost up to 25 times more and takes three times longer to be effective. Importantly, approximately $20 \%$ of MDR-TB cases are correctly diagnosed and strains are highly transmissible (3).

According to WHO, the most noteworthy pace of MDR-TB at any point recorded with tops up to $22 \%$ of new TB cases was in certain settings of the previous Soviet Union. In the same region, 1 in 10 cases of multi-drug resistant TB is XDR-TB. More than 400,000 cases of MDR-TB emerge worldwide every year as a result of under-investment in basic activities to control TB, poor management of anti-TB drugs and transmission of drug resistant strains. MDR-TB is much more difficult and costly to treat than drug sensitive TB (2).

WHO further declared that, is among the countries endemic to MDR-TB, the recent surveys showed an MDR-TB prevalence of $26 \%$ among TB patients in Ethiopia (retreatment cases), 54\% in Nigeria (tertiary hospital) higher in Portugal (32\%) than in Europe (7\%)(4).

The present evaluations of MDR-TB in Nigeria are $2.2 \%$ and $9.4 \%$ among new and retreatment cases respectively (5), 4.8\% MDR-TB in Nigeria, 2.9\% among HIV cases (6) and $14.3 \%$ in retreatment cases (7).

The age is accepted by WHO as a risk factor for drug resistance (8). Guidelines for surveillance of drug resistance in tuberculosis suggest data on drug resistance stratified by age groups. This fact can provide insight into risk groups and effectiveness of specifics TB control activities (9). Furthermore, the magnitude of drug resistance among younger age is more likely to be indicative of recent transmission than among older age groups, which are more likely to be harboring older infections (9).

Although in Nigeria resistance to anti-TB drugs is considered a priority, only few studies have focused on the relevant risk factors. This study aim to examine influence of controllable risk factors on development of drug resistant-tuberculosis among tuberculosis patients in Ibadan, Oyo State.

\section{Study population}

The study was descriptive cross-sectional survey using a three-stage systematic sampling technique to select 403 patients of tuberculosis patients in Ibadan North Local Government Area of Oyo State. Data was collected using a pre-tested, intervieweradministered, semi-structured questionnaire. The instrument included questions on socio-demographic characteristics, information-on pattern and prevalence of DR-TB, controllable risk factors that influence development of DR-TB, social life style influence the development of DR-TB patients and means of preventing controllable risk factors that influences development of DR-TB.

\section{Inclusion criteria}

Sputum positive pulmonary tuberculosis subject who had being on treatment (Isoniazid and Rifampicin) for minimum of one year

\section{Exclusion criteria}

Subjects below 18 years of age and critically ill patients were excluded from the study. 


\section{Statistical Analysis}

Data were collected using self administered structured questionnaire which entails socio demographic variable of the respondents, risk factors associated with occurrence of TB/MDR-TB and Previous TB treatment and compliance with treatment regimen, results were analyzed using SPSS version 25. Level of significance was set at $\mathrm{P}<0.05$. Results were expressed as Mean \pm Standard Error of Means (SEM). The level of statistical significance were considered $\mathrm{p}<0.05$.

\section{Ethical issue}

Ethical approval to conduct the research was obtained from Oyo State Ministry of Health Ethical Review Committees. Also permission to conduct the study was obtained from the State control Officer of TB programme and Management of Hospitals where MDR-TB is being managed and TB-DOT clinics in Ibadan.

\section{RESULTS}

Table 1 shows the socio demographic characteristics of the subjects, of the total 403 TB patients recruited for the study, less than one-fifth $53(13.2 \%)$ of them had been receiving treatment on MDR-TB prior to the period of this study (Table 4.2) there was no significant association between occurrence of MDRTB/TB and age.

(Table 4.2) shows the association between occurrence of MDR-TB/TB and socio demographic characteristics of the respondents, in the table education of the respondents shows a significant association with occurrence of MDR-TB/TB at $(p=0.007)$ with larger proportion of the respondents with MDR-TB in secondary schools 16(30.2\%), also larger proportion among the civil servants $17(32.1 \%)$ have previous history of MDR-TB at $(\mathrm{p}=0.000)$.

Table 1: Socio-Demographic Characteristics of the respondents $(\mathrm{N}=403)$

\begin{tabular}{|c|c|c|}
\hline Variable & Frequency & Percent $(\%)$ \\
\hline \multicolumn{3}{|l|}{ Gender: } \\
\hline Male & 234 & 58.1 \\
\hline Female & 169 & 41.9 \\
\hline \multicolumn{3}{|l|}{ Age: } \\
\hline $18-20$ years & 23 & 5.7 \\
\hline $19-39$ years & 205 & 50.9 \\
\hline 40 years and above & 175 & 43.4 \\
\hline \multicolumn{3}{|l|}{ Educational level } \\
\hline No formal education & 79 & 19.6 \\
\hline Primary School Leaving Cert. & 50 & 12.4 \\
\hline Secondary & 171 & 42.4 \\
\hline Tertiary & 110 & 27.2 \\
\hline \multicolumn{3}{|l|}{ Occupation: } \\
\hline Students / Unemployed & 16 & 4.0 \\
\hline Civil servant & 47 & 11.6 \\
\hline Retired civil servant & 15 & 3.7 \\
\hline Self employed & 228 & 56.6 \\
\hline Artisan & 68 & 16.9 \\
\hline Skilled worker (professional) & 29 & 7.2 \\
\hline \multicolumn{3}{|l|}{ Source of Income: } \\
\hline Fishing / farming & 40 & 9.9 \\
\hline Employment income & 74 & 18.4 \\
\hline Civil servant & 62 & 15.4 \\
\hline Business enterprise & 151 & 37.5 \\
\hline Property rental & 3 & 7 \\
\hline Traders & 73 & 18.1 \\
\hline \multicolumn{3}{|l|}{ Average Income Per Month } \\
\hline$\approx 20,000$ & 201 & 49.9 \\
\hline N21,000 - $N 50,000$ & 127 & 31.5 \\
\hline$\$ 51,000$ & 75 & 18.6 \\
\hline
\end{tabular}


Table 2: Association between occurrence of MDR-TB/TB and socio demographic characteristics of the respondents

\begin{tabular}{|c|c|c|c|c|c|}
\hline \multirow{2}{*}{ Variable } & \multicolumn{2}{|c|}{$\begin{array}{c}\text { Development of acquired } \\
\text { MDR-TB }\end{array}$} & \multirow{2}{*}{ Total } & \multirow{2}{*}{ statistic } & \multirow{2}{*}{ OR (95\% CL) } \\
\hline & MDR-TB & Non-MDR-TB & & & \\
\hline \multicolumn{6}{|l|}{ Gender } \\
\hline Male & $36(67.9)$ & $198(56.6)$ & $234(58.1)$ & \multirow{2}{*}{$\begin{array}{l}\chi^{2}=2.437 \\
\mathrm{df}=1, \mathrm{p}=0.119\end{array}$} & \multirow[t]{2}{*}{$1.787(0.95-3.35)$} \\
\hline Female & $17(32.1)$ & $152(43.4)$ & $169(41.9)$ & & \\
\hline \multicolumn{6}{|l|}{ Age } \\
\hline$\leqslant 18$ years & $2(3.8)$ & $21(6.0)$ & $23(5.7)$ & \multirow{3}{*}{$\begin{array}{l}\chi^{2}=0.629 \\
d f=2 \\
p=0.730\end{array}$} & \multirow[t]{3}{*}{$0.863(0.519-1.43)$} \\
\hline $19-39$ years & $29(54.7)$ & $176(50.3)$ & $205(50.9)$ & & \\
\hline$\geqslant 40$ years & $22(41.5)$ & $153(43.7)$ & $175(43.4)$ & & \\
\hline \multicolumn{6}{|l|}{ Educational level } \\
\hline No formal education & $10(18.9)$ & $69(19.7)$ & $79(19.6)$ & \multirow{4}{*}{$\begin{array}{l}\chi^{2}=24.640 \\
d f=5 \\
p=0.007\end{array}$} & \multirow[t]{4}{*}{$0.836(0.634-1.104)$} \\
\hline Primary & $8(15.1)$ & $42(12.0)$ & $50(12.4)$ & & \\
\hline Secondary & $16(30.2)$ & $155(44.3)$ & $171(42.4)$ & & \\
\hline Tertiary & $19(35.8)$ & $84(24.0)$ & $103(25.5)$ & & \\
\hline \multicolumn{6}{|l|}{ Socioeconomic status } \\
\hline Fishing/ Farming & $5(9.4)$ & $35(10.0)$ & $40(9.9)$ & \multirow{6}{*}{$\begin{array}{l}\chi^{2}=26.492 \\
d f=5 \\
p=0.000 *\end{array}$} & \multirow[t]{6}{*}{$1.348(0.950-1.913)$} \\
\hline Employment income & $16(30.2)$ & $58(16.6)$ & $74(18.4)$ & & \\
\hline Civil servant & $17(32.1)$ & $45(12.9)$ & $62(15.4)$ & & \\
\hline Business enterprise & $8(15.1)$ & $143(40.9)$ & $151(37.5)$ & & \\
\hline Property rental & $1(1.9)$ & $2(0.6)$ & $3(0.7)$ & & \\
\hline Traders & $6(11.3)$ & $67(19.1)$ & $73(18.1)$ & & \\
\hline
\end{tabular}

$\chi^{2}=$ Pearsons ${ }^{`}$ Chi-square, $\mathrm{df}=$ degree of freedom, $P=$ Probability value, $\mathrm{OR}=$ odd ratio, $\mathrm{CL}=95 \%$ confident interval

Table 3: Correlation matrix showing the relationship between risk factors of TB and Development of acquired

\begin{tabular}{|c|c|c|c|c|c|c|c|c|}
\hline $\begin{array}{l}\text { Variables } \\
\text { (sub-scales) }\end{array}$ & Mean & $\begin{array}{l}\text { Std. } \\
\text { Dev. }\end{array}$ & $\begin{array}{l}\text { Occurrence } \\
\text { of drug } \\
\text { resistant- } \\
\text { TB } \\
\end{array}$ & $\begin{array}{l}\text { Previous } \\
\text { TB treatment } \\
\text { \&Adherence with } \\
\text { treatment regimen }\end{array}$ & HIV & $\begin{array}{l}\text { Exposure to } \\
\text { incarceration }\end{array}$ & Smoking & $\begin{array}{l}\text { Alcohol } \\
\text { consump- } \\
\text { tion }\end{array}$ \\
\hline $\begin{array}{l}\text { Occurrence of drug } \\
\text { resistant-TB }\end{array}$ & 2.54 & 1.48 & 1. & & & & & \\
\hline $\begin{array}{l}\text { Previous TB treatment } \\
\text { \&Adherence with } \\
\text { treatment regimen }\end{array}$ & 1.91 & 0.42 & $0.270^{* *}$ & 1. & & & & \\
\hline HIV & 5.39 & 1.02 & $0.168^{* *}$ & 0.046 & 1. & & & \\
\hline $\begin{array}{l}\text { Exposure to } \\
\text { incarceration }\end{array}$ & 7.01 & 4.40 & 0.047 & $0.121 *$ & $0.323 * *$ & 1. & & \\
\hline Smoking & 4.61 & 2.13 & 0.074 & 0.006 & 0.064 & 0.093 & 1. & \\
\hline Alcohol consumption & 2.31 & 1.05 & 0.083 & 0.018 & $0.136^{* *}$ & $0.314 * *$ & $0.250^{* *}$ & 1. \\
\hline
\end{tabular}

*Correlation is significant at 0.05 (2-tailed) and ** Correlation is significant at 0.001 (2-tailed) 
Table 4: Regression showing relative risk factors associated with occurrence of drug resistant-tuberculosis

\begin{tabular}{|c|c|c|c|c|c|c|}
\hline \multirow[b]{2}{*}{ Variable } & \multicolumn{2}{|c|}{$\begin{array}{l}\text { Unstandardized } \\
\text { coefficients }\end{array}$} & \multirow{2}{*}{$\begin{array}{c}\text { Standardized } \\
\text { coefficients } \\
\text { Beta }(\boldsymbol{\beta})\end{array}$} & \multirow[b]{2}{*}{$\mathrm{T}$} & \multirow[b]{2}{*}{$\begin{array}{c}\text { Sig. } \\
(p \text {-value })\end{array}$} & \multirow[b]{2}{*}{$\mathrm{OR}(\mathrm{CL})$} \\
\hline & B & $\begin{array}{c}\text { Std. } \\
\text { Error }\end{array}$ & & & & \\
\hline Constant & 2.207 & 0.598 & & 3.689 & & \\
\hline $\begin{array}{l}\text { Previous TB treatment\& } \\
\text { adherence with treatment regimen }\end{array}$ & 0.969 & 0.168 & 0.274 & 5.761 & 0.000 & $0.276(0.11-0.70)$ \\
\hline $\begin{array}{l}\text { Human Immunodeficiency Virus } \\
\text { (HIV) }\end{array}$ & 0.263 & 0.073 & 0.181 & 3.615 & 0.000 & $2.068(0.16-2.73)$ \\
\hline Exposure to incarceration & 0.005 & 0.018 & 0.015 & 0.277 & 0.782 & $0.876(0.81-0.95)$ \\
\hline Smoking & 0.074 & 0.035 & 0.107 & 2.144 & 0.033 & $1.08(0.88-1.32)$ \\
\hline Alcohol consumption & 0.119 & 0.073 & 0.084 & 1.621 & 0.106 & $1.26(0.91-1.73)$ \\
\hline
\end{tabular}

Table 4.3 showed the inter-correlational matrix of the relationship between risk factors and occurrence of drug resistant-tuberculosis. The table revealed that previous TB treatment and Adherence with treatment regimen $(\mathrm{r}=0.270, p<0.05)$ and HIV $(\mathrm{r}=0.168, p<0.05)$ were independently and positively correlated with occurrence of drug resistanttuberculosis patients, exposure to incarceration $(\mathrm{r}=0.047, \quad p>0.05), \quad$ smoking $(\mathrm{r}=0.074, p<0.05)$, alcohol consumption $(\mathrm{r}=0.083, p>0.05)$ show no significant association.

Regression analysis relative to $\mathrm{TB}$ treatment and Adherence with treatment regimen (Table 4.4), in the table previous TB treatment and Adherence with treatment regimen, Human Immunodeficiency Virus (HIV) and risk factors (smoking) shows a significant association with occurrence of drug resistanttuberculosis at $(\beta=0.274, \mathrm{t}=5.761, \quad \mathrm{OR}=0.276)$, $(\beta=0.181, \mathrm{t}=3.615, \quad \mathrm{OR}=2.068)$ and $(\beta=0.107$, $\mathrm{t}=2.144, \mathrm{OR}=0.876$ ) respectively as $\mathrm{p}<0.05$ in each case.

\section{DISCUSSION}

In this study, gender was not statistically significant to MDR-TB this is contrary to the previous study conducted by Faustini et al. (10) who reported significant association between male gender and MDR-TB, more than two third of MDR-TB patients were male though not statistically significant. Males get exposed to the external environment than females and are at risk of MDR-TB due to nature of men work. However, Lomtadze et al. (11) concluded that female gender was statistically associated with MDR-TB. In a study conducted by Ukanwa and Madiba (12) also reported that more females $(63.6 \%)$ than males (36.4\%) were infected with MDR-TB, he submitted male gender has quick access to health care services when they get ill but females generally depend on other members of family to have access to health centres because they can't freely express their health problems.

Occupation of the respondents was significantly associated with the occurrence of MDR-TB. This is contrary to study conducted in the USA, in which no significant difference was found in participants' occupations and the occurrence of MDR-TB between the case and control groups (13) This finding is in line with other previous studies where, it was proven that low socio-economic status leads to poor adherence to treatment thereby leading to the development of MDR-TB, study conducted by Casal et al. (14) show that occupation was found to be significantly associated MDR-TB which is similar to this current study.

The type of job is connected with income and is an indicator of low socio-economic status. Several research reports indicated a high burden of MDR-TB among individuals of low socio-economic status (15, 9 ). The observed difference in this study might be attributed to differences in income status, Chen et al. (16) shown the co-relation between low family income and development of MDR-TB. Although family income was not statistically associated with the development of MDR-TB, most of the cases had low family income. Patients with a low family income might have more limited access to medical treatment and healthcare services. Also, their crowded and poor living conditions may facilitate the spread of infectious diseases.

Education of the subjects was significantly associated with occurrence of MDR-TB this corroborate with submission of Mahfuza et al. (17) who also reported education up to secondary level, service and business as occupation, past smoking 
status, and type 2 diabetes as comorbid illness as risk factors for MDR-TB.. in this study fewer proportion of the respondents were literate this may be responsible for poor adherence to the treatment which finally leads to the development of MDR-TB.

Several studies have shown that TB contact as strongest determinants of MDR-TB (18), this was reflected in the statistical association observed between TB contacts and MDR-TB. History of previous TB treatment was the strongest independent risk factor associated with MDR-TB, which is in line with findings of $(19,20)$. This imply that the usual practice of re-treating TB patient with first-line antiTB drugs without DST results is not an effective approach and may contribute to the persistence and continued spread MDR-TB strains in the community.

Most of the patients (73.7\%) in this study had previous history of TB. Study by (19) had shown a very significant correlation between past history of TB and MDR-TB, the experience of incompleteness of treatment was recorded as a serious predictor of MDR-TB in this study. This study is also in line with studies of Romeu and Trenga (21), Liu et al (22)whoreported previous treatment and poor adherence to treatment regimen influence development of drug resistant TB.

The occurrence of MDR-TB was strongly associated with previous treatment with anti-TB drugs. This finding is in line with the submission of (23), who reported thatdrug resistance of $\mathrm{M}$. tuberculosis to anti-TB drugs can occur when there is a history of incomplete or inappropriate TB treatment regimens lasting at least 1 month (29). This may be because prior inadequate anti-TB treatment only suppresses the growth of susceptible bacilli and does not affect other resistant strains, leading to suitable conditions for the dominant multiplication of preexisting drug-resistant mutants, which is a rise and fall phenomenon (24).

The current study showed that alcohol consumption was not associated with the occurrence of MDR-TB. Several reports, including one from the WHO (31), indicated that the use of alcohol increases the risk of developing MDR-TB due to poor adherence to treatment, impaired immune responses and an increased risk of adverse drug effects. As a result of these conditions, alcohol consumption was identified as an important population-level risk factor for MDR-TB (25). This study is in contrast to report of Zetola (26) who submitted that alcohol consumption influences development of MDR-TB.
Furthermore, it was evident from the findings of this study that smoking contributes significantly to development of MDR-TB. This study corroborates findings of Gómez-Gómezet al. (27) demonstrated that the smoking habit and alcoholism are strongly associated with MDR-TB. However, current finding infers that the smoking has co-relation with the development of MDR-TB.

In the current study HIV infecteion was independently associated with MDR-TB contrary to some previous study conducted in by $(19,20)$, this is however similar to other studies that have found association between HIV infection and MDR-TB (20). The difference in the studies is likely to have been attributed to variation in HIV prevalence between this study and other studies. In addition, a study by Andrews et al. (20) was conducted in population with high HIV and MDR-TB prevalence as well. Already, some studies have shown that drugresistant TB risk factors are likely to differ in settings with low and high prevalence of HIV and MDR-TB (28). So whether HIV infection per se increases the risk of drug resistance remains unclear, especially during this era of universal access to antiretroviral therapy and prophylaxis to infectious diseases.

Also, findings from this study showed that positive HIV status contributes relatively to development of drug resistant tuberculosis. The study also supports the reports of (29) who revealed there is high rate of DR-TB among HIV infected persons.

In addition, the study showed that exposure to incarceration is not a contributory factor to development of DR-TB. This study is thus in contrast to (30) and other studies that DR-TB is higher or more in congregate settings.

\section{CONCLUSION}

The results of this study provide information about potential risk factors that were found to be associated with MDR-TB status. Furthermore, although the prevalence of MDR-TB seems low, nevertheless, its potential risk to public health is important based on methods of diagnosis found in most of the major Hospitals coupled with poor sanitary measures thus a likelihood of nosocomial spread cannot be ruled out given a general lack of understanding about multidrug resistant strains. The study also identified gender to be associated with MDR-TB. Using these findings, it can be concluded that, previous history of TB treatment, smoking habit and history of contact 
with TB case were the risk factors associated with MDR-TB. Therefore, risk factors which are rarely emphasized in TB control strategies should be considered when formulating TB control policy to monitor patients with drug resistance TB. In addition, further studies should investigate mechanisms of how these predictors affect drug resistance. Based on the findings from this study, health care workers in TB settings should be adequately motivated in order to ensure uninterrupted healthcare services delivery this will avert fault and nonAdherence that are both programmatic and patient related. Efforts should be intensified on development of shorter regimen drugs for drug sensitive TB this will further promote good Adherence and treatment outcomes thereby preventing development of more resistant strains of TB bacteria.

\section{Potential conflict of interest}

No conflict of interest

\section{REFERENCES}

1. World Health Organisation. Global Tuberculosis Control: WHO report Geneva, Switzerland: 2016.

2. Abdulhalik Workicho Wondwosen Kassahun Fessahaye Alemseged, Risk factors for multidrugresistant tuberculosis among tuberculosis patients: a case-control study Infect Drug Resist. 2017; 10: 91-96. doi: 10.2147/IDR.S126274

3. Xin-Tong Lv, Xi-Wei Lu, Xiao-Yan Shi and Ling Zhou,Prevalence and risk factors of multi-drug resistant tuberculosis in Dalian, China Journal of International Medical Research 2017, Vol. 45(6) 1779-1786 DOI: 10.1177/030006051 6687429

4. Solomon WeldegebrealAsgedom, Mebrahtu Teweldemedhin, and Hailay Gebreyesus Prevalence of Multidrug-Resistant Tuberculosis and Associated Factors in Ethiopia: A Systematic Review Journal of Pathogens Volume 2018, Article ID 7104921, 8 pages https://doi.org/10.1155/2018/7104921

5. World Health Organization. Multi drug and Extensively drug resistant TB (M / X DR-TB), Global report on surveillance and response Geneva (2010) (WHO/HTM/TB/2010.3)

6. Ani AT, Idoko J, Dalyop YB, Pitman SL, Drug resistance profile of Mycobacterium tuberculosis isolated from pulmonary tuberculosis patients in Jos, Nigeria. Transaction of the Royal Society of Tropical Medicine and Hygiene (2009) 103: 87-71.

7. Kehinde AO, Obaseki FA, Ishola OC, Ibrahim KD
(2007) Multidrug resistance to Mycobacterium tuberculosis in a tertiary hospital. J Natl Med Assoc 99: 1185-1189.

8. Gomes, M., Correia, A., Mendonça, D. and Duarte, R. Risk Factors for Drug-Resistant Tuberculosis. Journal of Tuberculosis Research (2014) 2, 111-118

9. Marta Gomes, Ana Correia, DenisaMendonça, Raquel Duarte, Risk Factors for Drug-Resistant Tuberculosis Journal of Tuberculosis Research, 2014, 2, 111-118

10. Faustini, A., Hall, A.J., Perucci, C.A (2006). "Risk factors for MDR-TB in Europe: A systematic review".Thorax (2014) 61: 158-63.

11. Lomtadze, N., Aspindzelasvili, R., Janjgava, M., Mirtskhulava, V., Wright, A., Blumberg, H.M. and Salakaia, A. Prevalence and Risk Factors for Multidrug-Resistant Tuberculosis in Republic of Georgia: A Population Based Study. The International Journal of Tuberculosis and Lung Disease (2009), 13, 68-73.

12. Ukanwa and Madiba Being diagnosed with Multidrug resistant tuberculosis: Experiences of patients from rural KwaZulu Natal, South Africa nternational Journal of Recent Scientific Research, November, 2013Vol. 4, Issue,11, pp.1831-1834

13. Mesfin YM, Hailemariam D, Biadgilign S, Kibret KT. Association between HIV/AIDS and multi-drug resistance tuberculosis: a systematic review and meta-analysis. PLoS One. 2014; 9(1):e82235.

14. Casal, M., Vaquero, M, Rinder, H, Tortoli, E, Grosset, S. Rusch-Gerdes J and Jalier V. "A case-control study for multidrug-resistant tuberculosis: risk factors in four European countries." Microbial Drug Resistance, 2005: 11(1): 62-67.

15. Federal Ministry of Health (2015): NATIONAL Tuberculosis, Leprosy and Buruh ulcer management and control Guidelines sixth edition.

16. Chen S, Huai P, Wang X, Zhong J, Wang X, Wang K, Risk factors for multidrug-resistance among previously treated patients with tuberculosis in eastern china: a casecontrol study. International Journal of Infectious Diseases 2013: 17(12): 11161120. DOI: 10.1016/j.ijid.2013.06.006

17. MahfuzaRifat,' AbulHasnat Milton, John Hall, Christopher Oldmeadow, Md. Akramul Islam, Ashaque Husain, Md. and BodrunNaherSiddiquea Development of Multidrug Resistant Tuberculosis in Bangladesh: A Case-Control Study on Risk Factors PLoS One. 2014; 9(8): e 105214 PMCID: PMC4138182 doi: 10.1371/journal.pone.0105214

18. Kliiman, M.D. and Altraja, A. Predictors of 
Extensively Drug-Resistant Pulmonary Tuberculosis. Annals of Internal Medicine, 2009: 150, 766-775. http://dx.doi.org/10.7326/0003-4819150-11-200906020-00004

19. Marahatta et al: Risk factors for MDRTB in central NEPA! A Pilastudy Medical Journal 2010: 8(32) :392-7.

20. Andrews JR, Shah NS, Weissman D, Moll AP, Friedland G, et al. Predictors of Multidrug- and Extensively Drug-Resistant Tuberculosis in a High HIV Prevalence Community. PLoS ONE (2010) 5(12): e15735. doi:10.1371/journal. pone.0015735

21. Romieu, I. and C. Trenga, From exposure to disease: the role of environmental factors in susceptibility to and development of tuberculosis," Epidemiologic Reviews. 2001:“"23(2):288-301.

22. Liu, Q., Zhu, L., Shao, Y., Song, H., Li, G., Zhou, Y., Yang Z, Jinyan S, Chongqiao Z, Cheng $\mathrm{C}$ and Wei, L. Rates and Risk Factors for Drug Resistance Tuberculosis in Northeastern China. BMC Public Health, (2013) 13, 1171. http://dx.doi.org/10.1186/ 1471-2458-13-1171

23. Fikadu Tadesse, Risk Factors for Multi-drug Resistant Tuberculosis in Addis Ababa, Ethiopia Universal Journal of Public Health 3(2): 65-70, 2015 DOI: 10.13189/ujph.2015.030203

24. Mekonnen F, Tessema B, Moges F, Gelaw A, Eshetie S, Kumera G. Multidrug resistant tuberculosis: prevalence and risk factors in districts of metema and west armachiho, Northwest Ethiopia. BMC Infect Dis. 2015;15 (1):461

25. Shin SS, Mathew TA, Yanova GV, et al. Alcohol consumption among men and women with tuberculosis in Tomsk, Russia. Cent Eur J Public Health. 2010;18:132-138.

26. Zetola, NM, Modongo, C $\mathrm{C}^{*} \mathrm{Kip}, \mathrm{EC}$, Gross,R, Bisson, GP and Collman RG. Alcohol use and abuse among patients with multidrug-resistant tuberculosis in Botswana Int J Tuberc Lung Dis. 2012 Nov; 16(11): 1529-1534doi: 10.5588/ijtld. 12.0026

27. Gómez-Gómez A, Magaña-Aquino M, López-Meza $\mathrm{S}$, et al. Diabetes and Other Risk Factors for Multidrug Resistant Tuberculosis in a Mexican Population with Pulmonary Tuberculosis: Case Control Study. Arch Med Res. 2015;46(2): 142-148.

28. Mishal S Khan, Coll Hutchison, Richard J Coker, Joanne Yoong, Khaung M Hane,Anh L Innes, Tin M Khaing, SithuAung. Preventing emergence of drug resistant tuberculosis in Myanmar's transitioning health system Health Policy and Planning, Volume 32, Issue suppl_2, 1 October 2017, Pages ii43-ii50, https://doi.org/ 10.1093/heapol/czx093

29. Gomes, M, Correia A, Mendonca, D \&Duartes, R. Risk Factors for Drug Resistant Tuberculosis. Journal of Tuberculosis Research 2:111-118. Published Online September 2014 in SciRes. Available from: http://www.scirp.org/journal/jtr (accessed 27 July, 2018).

30. Abubakar, I, Zignol, M \&Raviglione M .Drugresistant tuberculosis: time for visionary political leadership. Elsevier. Available from: http://www. sciencedirect. com/science/article/pii/S147330 99137003062013 (accessed 7 July, 2018).

31. World Health Organization (WHO).Global tuberculosis report 2015 (internet). Geneva: WHO, 2015. (cited 2018 Jun 03) Available from: http://apps.who.int/iris/bitstream/10665/191102/1/9 789241565059_eng.pdf?ua=1

32. WHO, 2009 update TUBERCULOSIS FACTS

33. Ming-Gui Wang, Wei-Wei Huang, Yu Wang, Yun-Xia Zhang,(2018)Association between tobacco smoking and drug-resistant tuberculosis Infect Drug Resist. 2018; 11: 873-887 PMCID: PMC6003534 doi: 10.2147/IDR.S164596 